\title{
FLOWER OF ADENOCAULON BICOLOR
}

\author{
Jessie A. Ayres
}

\section{(WITH PLATES XI AND XII)}

Adenocaulon bicolor Hook. is distributed from the Himalaya Mountains to Japan, and from the northwestern part of the United States to Lake Superior. The only other species is $A$. chilenae Less., from Chile to the Straits of Magellan. The plant is a peculiar one, having no pappus, but an abundance of glandular hairs on the seed. This work was undertaken under the direction of Dr. T. C. FrYE of the University of Washington, with the object of comparing the development of the staminate and pistillate flowers.

The heads are arranged in a raceme (fig. I), which appears as a swelling between the upper leaves (fig. 2, s). On this swelling cycles of protuberances appear (fig. $3, a, c$ ), which become the bracts of the inflorescence subtending the peduncles; but the uppermost whorl becomes the involucre of the terminal head ( $c$ in figs. 4-9). When the involucre arches over the head, the primordia of the individual flowers appear as bulges on the receptacle (figs. 6 and $7, r^{\mathrm{I}}, r^{2}$ ). Some of the primordia divide, thus increasing the number of flowers (figs. 8-10, $x$ ). This mode of increasing the number of flowers suggests a tendency in the heads to branch, and points toward a probable ancestral form with scattered flowers. The axillary heads appear shortly after their bracts arise (fig. 9, b). The flowers develop in acropetal succession, as do the parts of the individual flowers (fig. Io).

In the staminate flowers, when the floral parts begin to develop, the flower primordia first broaden at the top (fig. 9, p). The corolla then appears as a marginal ring (fig. Io, $m r$ ) on the top. After the corolla tube lengthens and begins to curve inward, a ring of small bulges appears in the throat of the tube; these are the beginnings of the stamens (fig. Io, $s t$ ). When the stamens are well started, the carpels appear beneath them (fig. II, $r^{2}, c a$ ). Thus all the normal parts except the calyx are present (fig. I $2, r^{2}$ ). When the bundle enters the staminate flower, it separates into a 
whorl of five strands about a central strand. The latter terminates at the base of the sterile ovarian cavity; while the five strands about it pass up about the ovarian cavity until they reach half of its length (fig. $I_{3}, b^{\mathrm{x}}$ ). Then the two of these strands which are opposite to the two lobes of the stigma branch (fig. I3, $b^{2}$ ), each branch passing up into a lobe of the stigma. The main branch of each of these two strands and also the three other main strands pass up into the corolla, where each branches just below the base of its opposite stamen (fig. $\mathrm{I}_{3}, b^{3}$ ); one branch passes up into the stamen, and the main one continues up into the apex of the corolla. The fact that the stigma is cleft does not agree with descriptions in ENGLeR and PRANTL's Die natïlichen Pfanzenfamilien, BRITTON and BROwN's Illustrated flora, and HowELL's Flora of Northwest America.

In the pistillate flower the history is the same up to the development of the ovarian cavity. When the base of this cavity broadens (fig. I 2, $r^{\mathrm{I}}, o c$ ), a bulge appears, which is the beginning of the ovule.

The megaspore mother cell is formed in.the usual way, and occupies all or nearly all of the outer end of the nucellus. Behind the megaspore there is crowded a row of two or three other rather large cells, which gives the appearance of a row of three or four megaspores. Sometimes other cells remain at the side of the mother cell, and the outermost ones are often elongated and resemble the mother cell in size but not in content (fig. I4, $m u$ ). The megaspore mother cell passes through the usual two successive divisions, and the inner megaspore becomes the embryo sac (fig. 2I). The embryo goes through the same phases of cleavage (fig. 22) as those reported by MERRELL ${ }^{\mathrm{I}}$ in Silphium.

When the megaspore mother cell has enlarged (fig. I4), the first gland-hairs appear on the akene. Usually the first glands appear just where one would expect a calyx. This leads one to suspect that the tendency of the cells at that point to form projections is still slightly more marked than at other points. These glands develop from a protrusion of four epidermal cells of the akene. These cells are large and have large nuclei (fig. I5). They elongate and form a knob on the end (figs. I5-19). Many more glands

${ }^{2}$ BoT. GAZ. 29:115-I 24. 1900. 
appear shortly after the first ones. In the mature plant the whole inflorescence and the upper part of the stem is glandular, but no glands appear at all on the staminate flowers.

The paths of the axial bundles are the same as those in the staminate flowers, with two exceptions: first, the strand in the center of the whorl of five strands at the base of the ovarian cavity is not abortive, but passes into the ovule and curves with the integument to a point level with the antipodal cells (fig. 20, a); second, even when there are stamens no branch of the upper corolla strand branches into them. After fertilization, the style and corolla wither and drop off. When this happens, the whorl of five strands which lies adjacent to the integument (fig. 20,b) disorganizes and disappears, along with tissues which are also adjacent to the integument, thus freeing the ovary from the integument.

The style is cleft (fig. 20, sti) and the stigma is covered with papillae like those on the staminate flowers.

When the ovarian cavity begins to develop, the growth of the stamens is retarded. Usually they disappear, but sometimes remain as seen in fig. 20 , st, but none bearing pollen sacs were seen.

There was nothing unusual found in the formation of pollen grains. The outer wall layer becomes thick and spiny, while the spore becomes winged. In grooves between the wings, the extine is merely in contact. At the three germinative spots the walls are pushed outward (fig. 23). This occurs before the pollen grains leave the anther.

\section{Summary}

The development of the staminate and pistillate flowers is the same up to the development of the ovarian cavity.

Both staminate and pistillate flowers have ovarian cavities, but ovules develop only in the pistillate flowers.

Stamens are sometimes found in pistillate flowers, but they are always sterile.

No gland-hairs are found on staminate flowers.

Styles of staminate flowers are cleft.

Nothing unusual occurs in the development of the egg, embryo, or pollen grains. 
BOTANICAL GAZETTE, LIX

PLATE XI
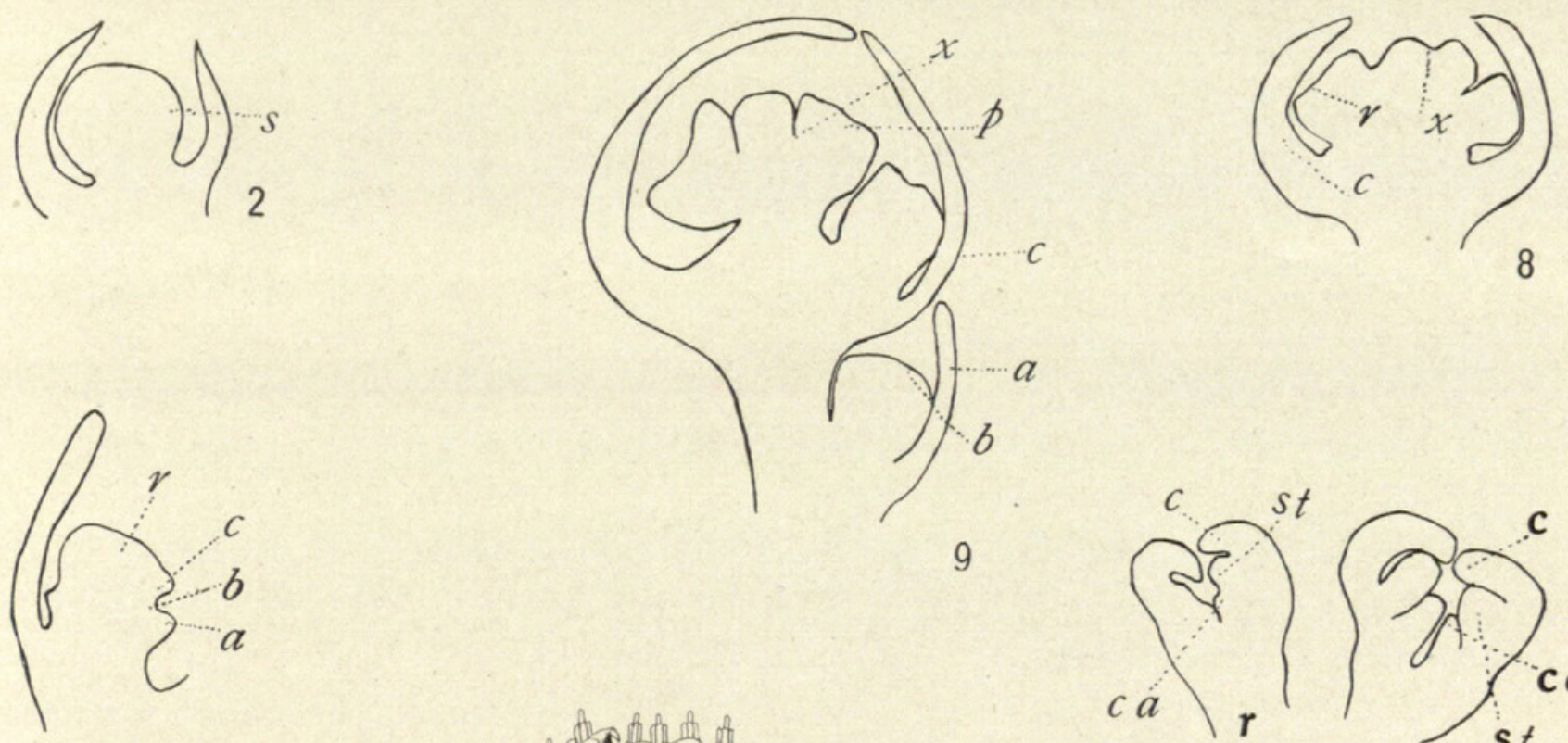

3
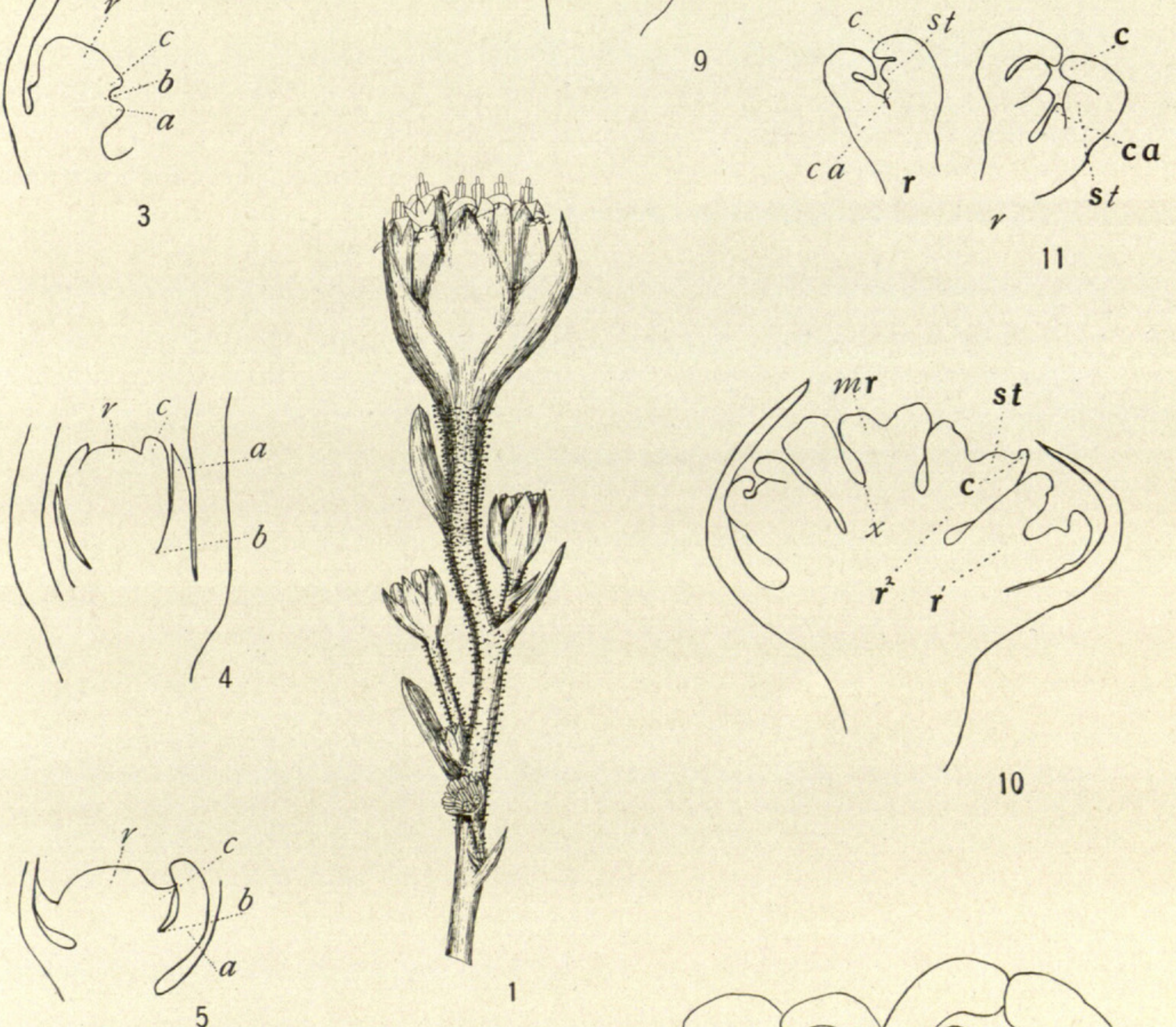

10
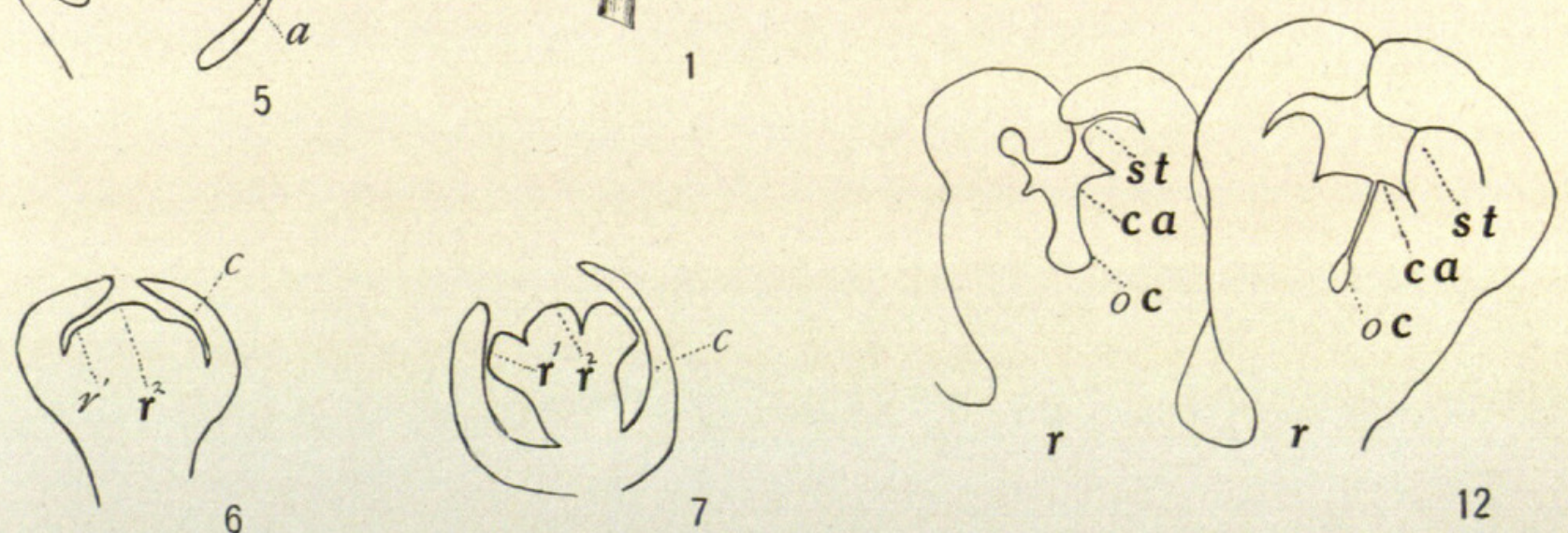

6 


\section{$2 \mathrm{BHL}$ Biodiversity Heritage Library}

Ayres, Jessie A . 1915. "Flower of Adenocaulon bicolor." Botanical gazette 59(2), 154-157. https://doi.org/10.1086/331509.

View This Item Online: https://www.biodiversitylibrary.org/item/109349

DOI: https://doi.org/10.1086/331509

Permalink: https://www.biodiversitylibrary.org/partpdf/223608

\section{Holding Institution}

Missouri Botanical Garden, Peter H. Raven Library

\section{Sponsored by}

Missouri Botanical Garden

\section{Copyright \& Reuse}

Copyright Status: Public domain. The BHL considers that this work is no longer under copyright protection.

This document was created from content at the Biodiversity Heritage Library, the world's largest open access digital library for biodiversity literature and archives. Visit BHL at https://www.biodiversitylibrary.org. 